\title{
EDITORIAL
}

Editor-in-Chief

\section{Make way for a new Editor-in-Chief of Spinal Cord...}

\author{
Lisa A. Harvey $\mathbb{1}^{1}$
}

Received: 22 October 2020 / Accepted: 22 October 2020

(c) International Spinal Cord Society 2020

The year 2020 will be forever ingrained in our memories as the year of COVID. We have all been personally affected by COVID one way or another, but those amongst us with spinal cord injuries have been affected more than most. I extend my condolences to those of you who have lost loved ones and my sympathies to those of you who have suffered from the consequences of COVID.

As the end of the year approaches it is customary to reflect on journal matters. I hope that does not appear insensitive in these difficult times.

Firstly, on behalf of the International Spinal Cord Society (ISCoS) and the journal I would like to sincerely thank the following members of the Editorial Board whose terms recently came to an end. They are:

- Dr. Susie Charlifue

- Professor Fin Biering-Sørensen

- Professor Andrei Krassioukov

- Professor Mary-Jane Mulcahey

- Professor Sarah Dunlop

- Professor John Steeves

All these people are well-known and highly respected in the field of spinal cord injury. It goes without saying that all have made impressive and valuable contributions to Spinal Cord over an extended period. I would like to particularly acknowledge Fin Biering-Sørensen who has been a member of the Editorial Board of Spinal Cord for over 30 years. Our records indicate that he has reviewed 177 papers for Spinal Cord in the last 15 years alone (and no doubt many more in the 15 years prior) and has published 140 papers in Spinal Cord (or its precursor, Paraplegia). Susie Charlifue and John Steeves also deserve special mention. In recent years Susie Charlifue took on the time-consuming task of editing the

\footnotetext{
$\triangle$ Lisa A. Harvey

1.harvey@usyd.edu.au

1 University of Sydney, Sydney, NSW, Australia
}

English of papers. I am extremely grateful to her for this, as are many authors. Associate Editor John Steeves has had an important influence on the direction of the journal.

As much as it hurts to farewell valued members of the Editorial Board, we have been delighted by the response to a call for new Editorial Board members. There were 36 applications from talented researchers and academics. We thank each of them and hope they will all continue to support Spinal Cord. The successful applicants are:

- Professor Kathleen Martin Ginis (Canada)

- Dr. Jörg Krebs (Switzerland)

- Professor Edelle Field-Fote (USA)

- Professor Anthony Burns (Canada)

- Professor Miguel Virseda-Chamorro (Spain)

- Professor Marc Ruitenberg (Australia)

A journal relies on the goodwill and hard work of all its reviewers. Spinal Cord has used the services of nearly 500 people to review manuscripts this year. The reviewers have provided invaluable advice, suggestions, and recommendations to authors and to me. I thank you all and hope you will continue to support the journal as a reviewer in years to come.

I want to make special mention of the Associate Editors, namely:

- Professor Marcel Post

- Professor Masaya Nakamura

- Dr. Sonja de Groot

- Professor Marcel Dijkers

- Professor Michael Fehlings

Few readers would know how much work the Associate Editors do behind the scenes and how important they are for the functioning of the journal. I have constantly called on the Associate Editors to provide advice and to manage manuscripts. Sonja de Groot established and continues to manage our social media presence, tweeting, and posting messages on Facebook nearly every day. The two Marcels 
are a constant source of wisdom. Masaya and Michael play a critical role in managing manuscripts that fall outside my area of expertise.

At the end of this year, after 4 years as Editor-in-Chief of Spinal Cord, I will be stepping down from that role. It has been a tremendous experience and I enjoyed nearly every moment of it. I will be forever grateful to ISCoS for entrusting me with their journal. The willingness of the ISCoS board to appoint me as Spinal Cord's first female Editor-in-Chief and first Editor-in-Chief from an allied health background is testament to forward thinking and the sign of a changing professional landscape. I think I can honestly say that I gave it my best. I hope that decisions I made were fair, transparent, and in the best interests of the journal.

Lastly, I would like to thank you: Spinal Cord's readers and authors. The journal relies on your loyalty and goodwill. I look forward to watching the journal grow from strength to strength, and reading future reports of highquality research that will improve the lives of people with spinal cord injuries. 